\title{
PENGEMBANGAN BAHAN AJAR BAHASA INDONESIA BERGAMBAR PADA MATERI “TEKS PERCAKAPAN" PADA SISWA KELAS V SD ST. YOSEPH MEDAN
}

\section{Nurcahaya Simaremare}

\section{Mahasiswa Magister Pendidikan Bahasa Indonesia Unimed}

\begin{abstract}
Abstrak
Pendidikan Bahasa Indonesia merupakan salah satu aspek penting yang perlu diajarkan kepada peserta didik di sekolah. Pendidikan Bahasa Indonesia sebagai salah satu mata pelajaran yang diberikan di sekolah diharapkan agar peserta didik mampu menguasai, memahami dan dapat mengimplementasikan keterampilan berbahasa. Selain itu belajar bahasa pada hakikatnya adalah belajar komunikasi. Oleh karena itu, pembelajaran bahasa diarahkan untuk meningkatkan kemampuan pembelajar dalam berkomunikasi, baik lisan maupun tulis.

Hasil pengembangan bahan ajar bahasa Indonesia bergambar pada materi teks percakapan diperoleh hasil validasi dengan kualitas yang sangat baik. Hal ini dapat dilihat dari validasi ahli materi 1 dengan persentase $85 \%$ dengan kategori sangat baik, validasi ahli materi 2 dengan hasil persentase 86,4\% dengan kategori sangat baik dan validasi oleh ahli bahan ajar dengan persentase $90 \%$ dengan kategori sangat baik. Maka dapat disimpulkan bahwa bahan ajar layak untuk dikembangkan dalam proses pembelajaran sebagai pendukung pencapaian keberhasilan pembelajaran dan ketercapaian tujuan pembelajaran. Hal utama yang mendukung keberhasilan kegiatan pembelajaran adalah strategi pembelajaran, metode atau model pembelajaran, dan media pembelajaran serta bahan ajar. Dalam hal ini pembelajaran Bahasa Indonesia difokuskan kepada penggunaan bahan ajar sebagai salah satu faktor pendukung guna membantu siswa dalam proses pembelajaran. Bahan ajar yang disampaikan guru hendaknya mengacu pada tujuan pembelajaran. Oleh karena itu, guru mempunyai keleluasaan untuk mengembangkan bahan ajar yang akan disampaikan sejauh tidak menyimpang dari tujuan pembelajaran.
\end{abstract}

Kata kunci : Bahasa Indonesia,bahan ajar, teks bergambar, teks percakapan. 


\section{PENDAHULUAN}

Sebagai seorang pendidik, guru dituntut untuk kreatif dalam proses belajar mengajar. Salah satunya yaitu dengan mengembangkan bahan ajar untuk kegiatan pembelajaran. Namun dalam kenyataanya, masih banyak sekolah dalam proses pembelajaran belum mengembang kan bahan ajar, salah satunya yaitu di SD St. Yoseph Medan

Dalam bahan ajar bahasa Indonesia, unsur bahasa sangatlah penting untuk diperhatikan. Pembelajaran bahasa diarahkan untuk meningkatkan kemampuan siswa untuk berkomunikasi dalam bahasa Indonesia yang baik dan benar. Namun pelaksanaan pembelajaran bahasa Indonesia di kelas V ini masih kurang bervariasi. Sehingga tujuan pembelajaran Bahasa Indonesia yang akan dicapai, yaitu siswa terampil berbahasa Indonesia baik lisan maupun tulisan yang mencakup 4 aspek (mendengarkan, berbicara, membaca, dan menulis) belum tercapai seperti yang diharapkan. Seperti pada mata pelajaran Bahasa Indonesia pada materi ajar "Teks Percakapan". Dalam materi ini siswa belum mengusai pelajaran dengan baik. Saat pembelajaran berlangsung, siswa kurang mendengarkan dan memperhatikan penjelasan guru. Sehingga pada saat guru menjelaskan mengenai materi teks percakapan, siswa belum paham mengenai materi yang diajarkan. Hal ini berpengaruh ketika siswa diminta membaca teks percakapan. Siswa cenderung hanya biasa saja dalam membaca teks percakapan tanpa memperhatikan lafal dan intonasi yang benar. Dalam penguasaan penggunaan tanda baca juga kurang tepat. Sehingga siswa belum dapat menulis sebuah teks percakapan yang sesuai dengan kaidah penulisan.

\section{TUJUAN}

Penelitian ini bertujuan untuk :

Menumbuhkan minat siswa untuk belajar Bahasa Indonesia dengan bahan ajar yang lebih menarik dari bahan ajar yang sebelumnya. Sehingga dengan adanya bahan ajar yang sudah dikembangkan ini, proses pembelajaran menjadi lebih menyenangkan

\section{Landasan Teori}

Menurut Borg and Gall (Zainal Arifin, 2012: 127) penelitian pengembangan adalah suatu proses yang dipakai untuk mengembangkan dan memvalidasi produk pendidikan. Bahan ajar adalah segala bentuk bahan yang disusun secara sistematis yang memungkinkan siswa dapat belajar dengan dirancang sesuai kurikulum yang berlaku. Dengan adanya bahan ajar, seorang guru akan lebih runtut dalam mengajarkan materi kepada siswa dan tercapai semua kompetensi yang telah ditentukan sebelumnya (Ika Lestari, 2013: 1). Menurut Ika 
Lestari, (2013: 5-6) bahan ajar memiliki beragam jenis, ada yang cetak maupun noncetak. Bahan ajar cetak yang sering dijumpai antara lain berupa handout, buku, modul, brosur, dan lembar kerja siswa. Sedangkan bahan ajar noncetak meliputi bahan ajar dengar (audio) seperti kaset, radio, piringan hitam, dan compack disc audio. Bahan ajar pandang dengar (audio visual) seperti video compack disc dan film. Bahan ajar multimedia interaktif (interactive teaching material) seperti CAI (Computer Assisted Instruction), compact disk (CD) multimedia pembelajaran interaktif, dan bahan ajar berbasis web (web based learning materials). Menurut Slamet, (2007: 6) pengajaran bahasa Indonesia pada hakikatnya adalah pengajaran keterampilan berbahasa, bukan pengajaran tentang bahasa. Tata bahasa, kosakata, dan sastra disajikan dalam konteks yaitu dalam kaitanya dengan keterampilan tertentu yang tengah diajarkan, bukan sebagai pengetahuan tata bahasa, teori pengembanagan kosakata, teori sastra sebagai pendukung atau alat penjelas. Keterampilan-keterampilan berbahasa yang perlu ditekankan pengajaran berbahasa Indonesia adalah keterampilan reseptif (keterampilan mendengarakan dan membaca) dan keterampilan produktif (keterampilan menulis dan keterampilan berbicara). Cecep dan Bambang, (2011: 45) mengemukakan bahwa gambar atau foto adalah media pembelajaran yang sering digunakan. Media ini merupakan bahasa yang umum, dapat dimengerti, dan dinikmati oleh semua orang dimana-mana. Gambar atau foto berfungsi untuk menyampaikan pesan melalui gambar yang menyangkut indera pengelihatan. Adapun pengertian gambar atau foto menurut Hujair, (2013: 81) adalah media yang paling umum digunakan orang, karena media ini mudah dimengerti dan dapat dinikmati, mudah didapatkan dan dijumpai dimana, serta banyak memberikan penjelasan bila dibandingkan dengan verbal. Menurut Edi Warsidi, (2008:10) percakapan hampir sama dengan wawancara. Baik dalam wawancara maupun percakapan, ada pihak yang bertanya dan pihak yang menjawab. Perbedaannya, dalam percakapan, penanya dan penjawab dapat berbicara bergantian, sedangkan dalam wawancara tidak demikian. Sedangkan menurut Sri Murni dan Ambar, (2008: 36) "percakapan bisa dilakukan oleh dua orang atau lebih. Menurut Djamarah, (2012: 19-24) prestasi belajar adalah penilaian pendidikan tentang kemajuan siswa dalam segala hal yang dipelajari di sekolah yang menyangkut pengetahuan atau kecakapan atau keterampilan yang dinyatakan sesudah hasil penilaian. Sedangkan menurut Fathurrohman dan Sulistyorini, (2012: 117) prestasi belajar adalah hasil yang ditunjukan siswa setelah melakukan proses belajar mengajar. 


\title{
Metode Penelitian
}

Dalam penelitian ini akan dilakukan pengumpulan data dengan cara meneliti kemampuan berbahasa terhadap berpikir kritis . Adapun data nara sumber adalah sebagai berikut.

\author{
Kelas $\quad$ : V SD \\ Sekolah $\quad$ : SD St. Yoseph Medan, Jl. Pemuda No 3a Medan
}

\section{HASIL PENELITIAN DAN PEMBAHASAN}

\section{Kualitas bahan ajar}

Kualitas bahan ajar dapat ditunjukkan pada hasil validasi oleh ahli materi dan ahli bahan ajar. Adapun hasil persentase penilaian kualitas bahan ajar, Hal ini dapat dilihat dari validasi ahli materi 1 dengan persentase $85 \%$ dengan kategori sangat baik, validasi ahli materi 2 dengan hasil persentase 86,4\% dengan kategori sangat baik dan validasi oleh ahli bahan ajar dengan persentase $90 \%$ dengan kategori sangat baik. Maka dapat disimpulkan bahwa bahan ajar layak untuk dikembangkan dalam proses pembelajaran sebagai pendukung pencapaian keberhasilan pembelajaran dan ketercapaian tujuan pembelajaran. Adapun hasil produk pengembangan bahan ajar ini adalah sebagai berikut. Gambar 1. Gambar Pengembangan Bahan Ajar

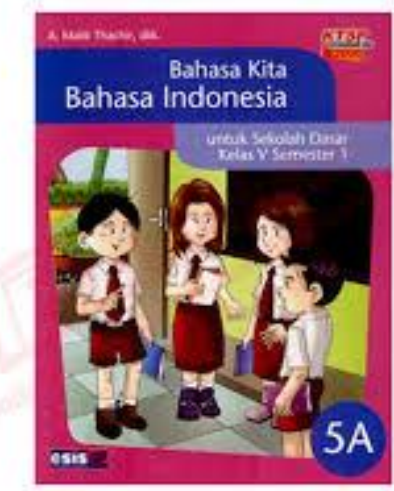

2. Daya Tarik Bahan Ajar berdasarkan Angket Respon Siswa

Adapun hasil persentase penilaian daya tarik bahan ajar berdasarkan respon siswa dapat ditunjukan bahwa Daya tarik bahan ajar diperoleh dari uji coba kelompok kecil, dimana siswa tertarik dengan pembelajaran menggunakan bahan ajar bergambar pada materi teks percakapan. Hal ini dapat dibuktikan dari hasil perolehan data dari pengisian angket diperoleh jumlah skor 326 dengan persentase 86,9\% sehingga masuk dalam kategori sangat menarik. Dengan adanya bahan ajar yang menarik dan tampilan gambar 
yang bervariasi, pembelajaran yang berlangsung menjadi lebih kondusif serta siswa aktif dan ekspresif. Siswa lebih aktif mengemukakan pendapat dan merespon guru.

Selain uji coba kelompok kecil dilakukan juga ujicoba kelompok besar. Keberhasilan ujicoba kelompok kecil, diberlakukan juga pada pembelajaran ujicoba kelompok besar untuk meningkatkan prestasi belajar siswa menggunakan bahan ajar berupa media gambar pada materi teks percakapan. Siswa lebih mandiri dalam menyelesaikan masalah atau pencarian jawaban atas tugas dari guru dengan tema yang sudah ditentukan. Siswa tertarik dengan bahan ajar karena bahan ajar yang disajikan menarik dengan tampilan gambar yang warna-warni dan bahasa yang mudah dipahami. Hal ini dapat dibuktikan dari hasil perolehan data dari pengisian angket diperoleh jumlah skor 2078 dengan persentase 92,3\% sehingga masuk dalam kategori sangat menarik.

3. Prestasi Belajar Siswa

Prestasi belajar adalah penilaian pendidikan tentang kemajuan siswa dalam segala hal yang dipelajari di sekolah yang menyangkut pengetahuan, kecakapan atau keterampilan yang dinyatakan sesudah hasil penilaian. Penilaian tidak hanya ditunjukan pada hasil tes berupa angka, tetapi juga pada penilaian sikap. Penilaian sikap yang dimaksud adalah bagaimana sikap atau perubahan ke arah yang lebih baik. penilaian sikap dalam penelitian ini menggunakan analisis observasi sikap siswa pada ujicoba kelompok kecil dan ujicoba kelompok besar. Analisis observasi sikap siswa pada saat ujicoba kelompok kecil menunjukan hasil perolehan persentase $88 \%$, sedangkan pada saat ujicoba kelompok besar memperoleh hasil persentase $89 \%$. Hal ini menunjukan bahwa sikap siswa selama pembelajaran pada saat menggunakan bahan ajar dengan media gambar lebih baik dalam menerima materi pelajaran. Siswa cenderung memperhatikan apa yang disampaikan guru menggunakan bahan ajar dengan media gambar sehingga siswa mudah memahami materi. Hasil positif ditunjukkan pada ujicoba kelompok kecil, dan kelompok besar sehingga bahan ajar dengan media gambar pada materi teks percakapan mata pelajaran Bahasa Indonesia dapat dikembangkan dan dipergunakan dalam pembelajaran.

Hal ini terbukti pada saat siswa diberikan tugas secara berkelompok untuk membuat teks percakapan berdasarkan tema dan gambar yang telah ditentukan. Kemudian siswa membacakan hasil kerja kelompok yang berupa teks percakapan di depan kelas. Setelah diamati oleh guru dengan menggunakan lembar penilaian sikap siswa, rata-rata siswa mampu menulis teks percakapan sesuai dengan tanda baca yang tepat. Selain itu siswa juga mampu membaca dengan lafal dan intonasi yang tepat. Siswa juga memperhatikan ketika temanya sedang mempresentasikan hasil kerja kelompok lain. Penggunaan bahan 
ajar dengan media gambar sudah menunjukan hasil yang baik dengan tercapainya tujuan pembelajaran yang mencakup penilaian 4 aspek yaitu mendengarkan, berbicara, membaca dan menulis. Indikator pencapaian prestasi belajar berupa angka ditunjukan dengan alat ukur pencapaian dan peningkatan rata-rata prestasi belajar siswa pada kegiatan pembelajaran. Alat ukur yang digunakan adalah soal pretes dan postes setelah menggunakan bahan ajar dengan media gambar. Kegiatan pembelajaran ini menunjukkan adanya peningkatan bahwa media pembelajaran akan mempengaruhi nilai yang diperoleh siswa yaitu menjadi maksimal. Karena pembelajaran terkesan lebih menarik dan tidak konvensional, siswa ikut terlibat aktif dalam kegiatan pembelajaran sehingga siswa lebih memahami apa yang disampaikan guru. Peningkatan dilihat dari perolehan nilai pretes maupun postes terjadi perbedaan rata-rata skor, hal ini menunjukkan adanya peningkatan rata-rata perolehan nilai yaitu dari 6,1 menjadi 8,2. Nilai tersebut sudah diatas KKM yang telah ditentukan sekolah yaitu 75. Sehingga dapat disimpulkan bahwa ada peningkatan rata-rata prestasi belajar siswa setelah menggunakan bahan ajar dengan media gambar pada materi teks percakapan.

\section{SIMPULAN}

Berdasarkan hasil penelitian pengembangan ini dapat disimpulkan sebagai berikut.

1. Hasil pengembangan bahan ajar bahasa Indonesia bergambar pada materi teks percakapan diperoleh hasil validasi dengan kualitas yang sangat baik. Hal ini dapat dilihat dari validasi ahli materi 1 dengan persentase $85 \%$ dengan kategori sangat baik, validasi ahli materi 2 dengan hasil persentase $86,4 \%$ dengan kategori sangat baik dan validasi oleh ahli bahan ajar dengan persentase $90 \%$ dengan kategori sangat baik. Maka dapat disimpulkan bahwa bahan ajar layak untuk dikembangkan dalam proses pembelajaran sebagai pendukung pencapaian keberhasilan pembelajaran dan ketercapaian tujuan pembelajaran.

2. Respon siswa terhadap bahan ajar bahasa Indonesia bergambar pada materi teks percakapan yang telah dikembangkan pada ujicoba kelompok kecil diperoleh hasil dengan jumlah skor 326 dengan persentase 86,9\% sehingga masuk dalam kategori sangat menarik, begitu juga dengan respon siswa pada uji coba kelompok besar dengan jumlah skor 2078 dengan persentase 92,3\% sehingga masuk dalam kategori sangat menarik. Maka dapat disimpulkan bahwa siswa tertarik dengan bahan ajar media gambar yang digunakan dalam pembelajaran, karena bahan ajar yang dikembangkan sangat menarik. 
3. Hasil perolehan nilai rata-rata pretes dari keseluruhan siswa yaitu 6,1, sedangkan perolehan nilai rata-rata postes dari keseluruhan siswa yaitu 8,2. Berdasarkan hasil perolehan nilai ratarata pretes dan postes menunjukan adanya peningkatan rata-rata nilai siswa sebelum dan setelah diberikan produk bahan ajar dengan media gambar.

Dengan demikian dapat disimpulkan bahwa ada peningkatan nilai rata-rata prestasi belajar siswa setelah menggunakan bahan ajar bahasa Indonesia bergambar pada materi teks percakapan. Hal ini juga dapat dilihat dari penilaian sikap siswa selama pembelajaran. Analisis observasi sikap siswa pada saat ujicoba kelompok kecil menunjukan hasil perolehan persentase $88 \%$, sedangkan pada saat ujicoba kelompok besar memperoleh hasil persentase $89 \%$. Hal ini menunjukan bahwa sikap siswa selama pembelajaran pada saat menggunakan bahan ajar dengan media gambar lebih baik dalam menerima materi pelajaran. Sehingga tujuan pembelajaran yaitu siswa terampil berbahasa Indonesia baik lisan maupun tulisan yang mencakup 4 aspek (mendengarkan, berbicara, membaca, dan menulis) dapat tercapai seperti yang diharapkan.

\section{DAFTAR PUSTAKA}

Andi Prastowo. 2013. Panduan Kreatif Membuat Bahan Ajar Inovatif. Jakarta: Diva Press.

Andi Prastowo. 2014. Pengembangan Bahan Ajar Tematik. Jakarta: Kencana Prenada media Group.

Baharudin dan Esa Nur Wahyuni. 2007. Teori Belajar dan Pembelajaran. Yogyakarta: AR-Ruzz Media.

Cecep Kustandi dan Bambang Sutjipto. 2011. Media Pembelajaran. Bogor: Ghalia Indonesia.

Daen Nurjamal, dkk. 2011. Terampil Berbahasa. Bandung: Alfabeta CV.

Daryanto dan Aris Dwicahyono. 2014. Pengembangan Perangkat Pembelajaran. (Silabus, RPP, PHB, Bahan Ajar. Yogyakarta: Gava Media.

Edi Warsidi dan Farika. 2008. Bahasa Indonesia membuatku cerdas 5: untuk kelas V Sekolah Dasar dan Madrasah Ibtidaiyah. Jakarta: Pusat Perbukuan, Departemen Pendidikan Nasional.

Eko Putro Widoyoko. 2014. Teknik Penyusunan Instrumen Penelitian. Yogyakarta: Pustaka Pelajar. 
Gede Nurjaya. 2012. "Pengembangan bahan ajar metode pembelajaran bahasa dan sastra Indonesia berbasis pembelajaran kooperatif Jigsaw untuk meningkatkan pemahaman dan kemampuan aplikatif mahasiswa”. Jurnal Pendidikan Bahasa: 102-109.

Hujair AH Sanaky. 2013. Media Pembelajaran Interaktif-Inovatif. Yogyakarat: Kaukaba Dipantara.

Ika Lestari. 2013. Pengembangan Bahan Ajar Berbasis Kompetensi (Sesusai dengan kurikulum tingkat satuan pendidikan). Padang: Akademia Permata.

Meina Febriani. 2012. "Pengembangan bahan ajar apresiasi dongeng Banyumas bagi siswa SD kelas rendah”. Jurnal Pendidikan Sastra dan Bahasa 1(1). Universitas

Negeri Semarang: 1-7.

Muhammad Fathurrohman dan Sulistyorini. 2012. Belajar dan Pembelajaran (Membantu meningkatkan mutu pembelajaran sesuai standar nasional). Yogyakarta: Teras. 